\title{
SURVEY ON HELMINTHIC AND PROTOZOAN CONTAMINATIONS IN ALIMENTARY CANAL OF OSTRICH AT TEHRAN PROVINCE SLAUGHTERHOUSES
}

\author{
S. Jalal Mirian*, A. Reza Mohammadi, G. Karimi, K. Ismail Nia, G. Motamedi, H. Hamidiyeh, \\ M. Ghadiri
}

Razi Vaccine and Serum Research Institute Agricultural Research, Education and Extension Organization (AREEO), Tehran, Iran

Published online: 15 February 2017

\begin{abstract}
Ostrich- farming has been prevalent in South Africa as the main habitat of this bird since several centuries ago and the flocks of ostrich have been reared similar to other herds or tame animals and flocks of birds. It can be also possibly reared in other countries of the world. At present, whereas skin, flesh, and other organs of this bird are consumed thus farming of this bird is vitally important in the world.

With respect to growing population of ostrich flocks in Tehran Province and the affiliated towns and importance of this issue in terms of providing meat and protein for the consuming market and in order to improve production yield it requires for diagnosis of and prophylaxis of the related common diseases for this animal particularly the parasitic diseases. It was tried to study by referring to 16 ostrich farming centers and visiting and sample from 55 carcasses of and or fatalities of the animal for this purpose. Then, after washing the contents of intestine of this bird and passing of those through screen (100) and staining with loop they were analyzed. Also lamella was prepared from intestinal wall and after staining the probability of existing protozoans was explored. No helminthic parasite was observed in the samples and Emeria oocyte was seen in three cases.
\end{abstract}

Keywords: Helminthic and protozoan parasites, Ostrich, Tehran Province

doi: http://dx.doi.org/10.4314/jfas.v9i1s.734 


\section{INTRODUCTION}

Although this animal is resistant against most of prevalent viral, bacterial, parasitic, and fungal diseases, some of parasitic vectors may reduce production and morbidity in ostrich farms. The prevalent parasitic diseases in ostrich include nematodes of nippostrongylus, Codiostomum struthionis, filarial, Houttuynia struthionis isolated from ostriches (Huchzermeyer, 2002). However, there are few case reports inside Iran including a study which was carried out by Islami et al (2006) on alimentary parasites of ostrich in which they have isolated some forums from Douglas nippostrongylus and hetraxis dispar (Huchzermeyer, 1995). In another study done by Masoudi Rad in Mashhad (2008), no parasite was isolated (6). Several studies have been conducted about protozoans in ostrich abroad that signified the presence of parasitic protozoans including isospora, cryptosporidiae, trichomonas, giardia, blastocystis gali, and balantidium isosthionis in alimentary canal of ostrich $(11,12)$. Ostrich is never contaminated by fowl Imeria (Huchzermeyer, 2002). In a report about fatalities of ostrich chickens in Russia, isospora strathionis has been isolated (Huchzermeyer, 2002).

In a study done by Eslami et al (2007) in some of ostrich farms in Iran, analysis was conducted to study on helminthic parasites in digestive system in which it has been referred to isolation of parasitic oocytes, due to inadequate quantity of them, it was not possible to execute sporulation and identifying them (Huchzermeyer, 1995). Giardia varieties have been isolated in ostriches in the US in 1992, 1994, and 1995 (12).

\section{MATERIALS AND METHODS}

According to the available information from deputy of improvement of livestock products in Agri-Jihad Organization in Tehran Province, there are 34 farming center for egg-layer ostrich and 16 farming units for meat ostrich with exploitation license in Tehran Province. In some cases there were some ostrich for slaughterhouse, five units for slaughtering of livestock killed the ostrich for consumption. From November 2010 through November 2013, if there was any fatality or slaughtering of ostrich, the researcher referred to the farming site or slaughterhouse and after recording specifications of the slaughtered carcasses they did autopsy and removed the digestive system of the subject and transferred it with icepack to the laboratory of veterinarian division of the research center. After isolation of the contents of any part of alimentary canal in laboratory (including small intestine, rectum, and large intestine) and washing of the contents the researcher 
has screened it and collected the rest existing residues from the screen into plastic vessels and it was accurately inspected to explore matured parasite. The sample was observed by Logul's iodine solution and with loop to increase accuracy and isolated it by worm-collection needle if there was doubt about presence of parasite and put it in petri and bleached by thiosulphate and placed in glycerin alcohol (70\%) and the intestinal mucus was prepared widely from this area to examine digestive protozoans and stained it by modified Ziel-Nelson technique and observed under microscope. And the sample was prepared from feces inside rectum and examined for observation of eggs of parasites by cleansing technique of Clayton Lin.

Table 1: Specification of ostrich farming centers in Tehran Province of which samples have been extracted:

\begin{tabular}{|c|c|c|c|c|}
\hline Farm code & Farming site & $\begin{array}{c}\text { Number of } \\
\text { carcasses }\end{array}$ & $\begin{array}{c}\text { Age of } \\
\text { ostriches }\end{array}$ & $\begin{array}{l}\text { Gender of } \\
\text { ostriches }\end{array}$ \\
\hline 1 & $\begin{array}{l}\text { Khalilabad- } \\
\text { Varamin }\end{array}$ & 2 & 12 months & Male \\
\hline 2 & $\begin{array}{c}\text { Gharchak- Great } \\
\text { Goltapeh }\end{array}$ & 3 & 12 months & Male \\
\hline 3 & $\begin{array}{l}\text { Bagher Abad- } \\
\text { Varamin }\end{array}$ & 3 & 12 months & Male \\
\hline 4 & $\begin{array}{c}\text { Pishva- Ghaleh } \\
\text { Band }\end{array}$ & 3 & 14months & male \\
\hline 5 & Kahrizak & 4 & 13 months & $\begin{array}{c}\text { Two males and } \\
\text { two females }\end{array}$ \\
\hline 6 & $\begin{array}{l}\text { Salman Abad } \\
\text { Shahr-E-Rey }\end{array}$ & 4 & 5months & $\begin{array}{c}\text { One female and } \\
\text { three males }\end{array}$ \\
\hline 7 & $\begin{array}{l}\text { Darsoon Abad- } \\
\text { Shahr-E-Rey }\end{array}$ & 3 & 3, omths & Male \\
\hline 8 & $\begin{array}{l}\text { Dotooyeh- } \\
\text { Kahrizak }\end{array}$ & 4 & 12 months & Male \\
\hline 9 & Azizabad- Varamin & 3 & 14months & Male \\
\hline 10 & Jalil Abad- & 4 & 12 months & Female \\
\hline
\end{tabular}




\begin{tabular}{|c|c|c|c|c|}
\hline & Varamin & & & \\
\hline 11 & $\begin{array}{c}\text { Basim-Goosht } \\
\text { slaughterhouse }\end{array}$ & 10 & 14 months & $\begin{array}{c}6 \text { males- } \\
\text { females }\end{array}$ \\
\hline 12 & Robat Karim & 3 & 3 months & Male \\
\hline 13 & Mallard & 2 & 4 months & Male \\
\hline 14 & $\begin{array}{c}\text { Ahmad Abad } \\
\text { Mostofi }\end{array}$ & 2 & 5 months & Female \\
\hline 15 & Safadasht & 3 & 12 months & Male \\
\hline 16 & $\begin{array}{c}\text { Hassan Abad } \\
\text { Fashapooyeh }\end{array}$ & 2 & 5 years & Male \\
\hline
\end{tabular}

\section{RESULTS}

Overall, 55 samples of alimentary canal were prepared from 15 farming units and one slaughterhouse and examined in vitro and no worm or helminthic egg was found in these samples.

All collected samples from slaughterhouse and ostrich farming centers in Tehran Province have been shown in Table (1) separately based on age and gender in Table (1).

No matured parasite and egg of parasite was observed in studies out of the given samples in vitro but three carcasses of Emeria oocyte were isolated but there was no possibility for sporulation and identifying of them because of few numbers of them.

\section{DISCUSSION AND CONCLUSION:}

Given that the host ostrich has been imported from abroad into Iranian ecosystem and the relevant diseases of this animal should be examined including parasitic diseases. In current study which has been carried out from November 2010 through November 2013, 55 samples of alimentary canal were studied in vitro out of total 15 farming units and one slaughterhouse for livestock and no helminthic parasite and parasitic egg was isolated. Most of researchers have not also isolated any specific parasite in the former conducted investigations on parasites among ostriches in Iran and only in one of farming units locating at north Iran (Nashtarood town), Eslami et al could isolate Douglas Nippostrongylus, Hetraxis disper from ostriches of a farm (Huchzermeyer, 1995). In another study which was done by Masoudi (2008) in Mashhad, no 
parasite has been isolated (Masoudi Rad, 2008). The studies conducted about protozoans in ostrich abroad they signified presence of parasitic protozoans of isospora, cryptosporidia, trichomonas, Giardia, blastocystis gali, and balantidium isosthionis in alimentary canal of ostrich. The ostrich is never contaminated by avian Emeria (Huchzermeyer, 2002; Hyun's, 2000). In a report about fatalities of young ostriches in Russia, they have been isolated due to isospora strathionis (Huchzermeyer, 2002).

In a study done by Eslami et al (2007) in some of ostrich farming units of Iran, the objective of that survey was to explore helminthic parasites in digestive system in which it has been referred to isolation of parasitic oocytes for which it was not possible to conduct sporulation and recognizing them because of inadequate quantity of them (Huchzermeyer, 1995).

Thus, given that majority of ostrich farming units are closed and lack of free grazing in Tehran Province and also the ostriches are given anti-parasitic drug at least twice a year therefore no one should expect to see parasitic contaminations. Meanwhile, most of presently studied ostriches were farmed for meat and they have usually at age of one year while most of parasitic contaminations have been reported further in egg-layer and older livestock. No specific parasite has been also isolated in studies of other researchers and one case of parasitic contamination was reported by Eslami et al locating in Nashtarood town and it was because of special climatic conditions in North Iran and availability of free grazing for ostriches (of course, the aforesaid ostriches were imported ones and their contamination has been probably traced in their origin) and also no case has been reported about ostriches placed in other studied provinces. In another investigation done by Sharaeeini about review on reason for fatalities in ostriches locating in Tehran province, no case of parasitic disease has been observed (Sharaeeini, 2003).

It seems the above-said cases apply to parasitic protozoans and there is no report about isolation and recognition of parasitic protozoans inside Iran. Therefore, with respect to above-mentioned cases, it seems helminthic contaminations are not too important in ostriches at Tehran province. So, it is also suggested about contamination of protozoans that to study on egg-layer ostriches and younger ones than three months in researching projects in order to judge about the results better.

\section{REFERENCES:}

1- Ohadi Nia, Hassan (1999), Practical farming and ostrich diseases 
2- Hamidiyeh, Hormuz (2002), Ostrich diseases, Nikkhah Pub

3- Hamidiyeh, Hormuz (Comprehensive principles of diseases and rearing of ostrich- Nikkhah Publication Center- 230 pages

4- Razmjoo, Mostafa (1998), Rearing and diseases of ostrich

5- Shahraeeini, Amir (2003), Analysis of reasons for fatalities in rearing forums of ostrich Tehran outskirt- PhD Thesis of veterinary medicine from Islamic Azad University of Karaj branch, no 617

6- Masoudi Rad, Ramin (2008), Survey on parasitic contaminations of digestive system in Mashhad ostrich farms, fifteenth congress on veterinary congress in Tehran

7-Andrens kreibich, Mathias summer (1995) ostrich farm Management.

8-E. Fowler Murray (1993) Zoo and wild animal medicine current therapy Pp399.

9-Eslami A et al (2007) Gastrointestinal parasites of ostrich raised in iran Iranian Journal of vet research university of Shiraz vol. 8,No23.

10-F. W. Huchzermeyer (1995) diseases of ostriches and other ratites. Onderstepoort veterinary Insititute-ARC-LYR publication. Pp.260.

11-F. W. Huchzermeyer (2002) diseases of Ostriches. Rev. sci. tech. off. int. Epiz. 21 (2): 256276.

12-Hyun's. Lillehog. and Erik P. Lillehog (2000) Avian Coccidiosis. A review of acquired intestinal immunity and vaccination strategies Avian diseases. 44; 408-425.

13-McDougald, L. R., and W. M. Reid. (1997) Coccidiosis Diseases of poultry, 10th ed. B. W. Calnek, ed, Iowa state university Press. Anes, IA, pp. 865-883.

14-Jordon, F. T. W. (1990) Poultry diseases. Third edition, Bailliere Tindall. pp:226-241

\section{How to cite this article:}

Jalal Mirian S, Reza Mohammadi A, Karimi G, Ismail Nia K, Motamedi G, Hamidiyeh H, Ghadiri M. Survey on helminthic and protozoan contaminations in alimentary canal of ostrich at tehran province slaughterhouses. J. Fundam. Appl. Sci., 2017, 9(1S), 808-813. 